\title{
Excretion-Reuptake Route of $\beta$-Hexosaminidase in Normal and I-Cell Disease Cultured Fibroblasts
}

\author{
Georgirene D. Vladutiu and Mario C. Rattazzi, Division of Human Genetics, \\ Department of Pediatrics at Children's Hospital, State University of \\ New York at Buffalo, Buffalo, New York 14222
}

A B S T RAC T It has been proposed that in cultured fibroblasts the final packaging of enzymes in lysosomes requires excretion followed by pinocytosis by neighboring cells via a carbohydrate-specific receptor mechanism. It has also been proposed that the abnormally high activity of lysosomal enzymes in the medium of cultured fibroblasts from patients with I-cell disease (mucolipidosis II) results from an altered carbohydrate recognition residue on the enzymes which prevents reuptake into the cells. With $\beta$-hexosaminidase as a marker, and competitive inhibition of uptake by $2 \mathrm{mM}$ mannose-6-phosphate, we have determined that only $12 \%$ of the total (intra- and extracellular) $\beta$-hexosaminidase in normal fibroblasts is channeled through the excretion-reuptake route. After $9 \mathrm{~d}$ of exposure to mannose-6-phosphate, normal fibroblast cultures accumulated in the medium only a fraction of the enzyme excreted by I-cell disease fibroblasts in the same period. Furthermore, this minimal loss of enzyme to the medium did not result in a decrease of intracellular enzyme activity. Finally, if the defect in I-cell disease were only because of an impairment of a reuptake mechanism that involves only $12 \%$ of the total enzyme, then $88 \%$ of the newly synthesized enzyme should be retained by I-cell fibroblasts, resulting in intracellular activity three to nine times higher than that which is observed. These data are consistent with our previous proposal that excessive lysosomal enzyme activity in the medium of I-cell disease fibroblasts results from preferential exocytosis.

\section{INTRODUCTION}

I-cell disease (mucolipidosis II) is an inherited neurodegenerative disorder clinically similar to the mucopolysaccharidoses, in which the primary biochemical

Dr. Rattazzi is the recipient of National Institutes of Health Research Career Development Award KO4-GM70638.

Received for publication 8 June 1978 and in revised form 18 December 1978. lesion is unknown. Cultured skin fibroblasts from these patients have been found to be partially deficient in several lysosomal hydrolases (1) with the corresponding enzyme activities in the culture medium increased severalfold over normal (1).

It has been observed that a number of lysosomal enzymes from I-cell disease fibroblast culture medium are not pinocytosed by non-I-cell fibroblasts, whereas I-cell fibroblasts can take up enzyme excreted by normal fibroblasts (2). This finding has led to the hypothesis that in fibroblasts, the final packaging of lysosomal enzymes requires intercellular cooperation, whereby the hydrolases secreted by normal fibroblasts are pinocytosed by neighboring cells via receptors that interact with a carbohydrate "recognition marker" on the enzyme (3). All available evidence with respect to uptake of human fibroblast-derived enzymes by human fibroblasts thus far indicates that uptake is via a specific mannose-6-phosphate-inhibitable mechanism (4-7). Hickman and Neufeld (2) have suggested that the recognition marker is defective in I-cell disease fibroblastexcreted enzymes, hence the enzymes are not pinocytosed and accumulate in the medium.

There has been no experimental evidence presented so far that directly substantiates or refutes the excretion-reuptake hypothesis of Hickman and Neufeld (2). By using the strong inhibitory property of D-mannose6-phosphate in preventing the uptake of exogenous enzyme by fibroblasts (4), we have attempted to determine the proportion of endocellular lysosomal hydrolases excreted and recaptured by normal cells, as well as whether an impairment of the postulated reuptake route alone can account for the excess of lysosomal hydrolases found in I-cell fibroblast culture medium, with a corresponding intracellular depletion. Our results, obtained with $\beta$-hexosaminidase ( $\beta$-D- $N$-acetylglucosaminidase, EC 3.2.1.30) as a marker, indicate that $\cong 12 \%$ of the normal fibroblast's enzyme is engaged in excretion and reuptake via the mannose-6-phosphate inhibitable route, and that impaired uptake of this fraction does not explain the I-cell disease phenomenon. 


\section{METHODS}

Cell culture. A normal fibroblast culture and fibroblast cultures from Sandhoff- and I-cell disease patients were obtained as previously described $(8,9)$. All cultures were maintained in 25- $\mathrm{cm}^{2}$ disposable flasks (Corning Glass Co., Corning, N. Y.), in Ham's F-10 medium containing $15 \%$ fetal calf serum (Grand Island Biologicals Co., Grand Island, N. Y.), and kanamycin $(20 \mu \mathrm{g} / \mathrm{ml})$. Methods for the harvesting, counting, and extracting of fibroblasts have been previously described (8).

Enzyme preparations. Preparations of "low-uptake" $\beta$ hexosaminidase were obtained by collection and concentration of serum-free Ham's F-10 medium containing hexosaminidasefree human serum albumin $(0.25 \%$ final concentration) from 4 to 7 -d-old roller bottle cultures of normal fibroblasts (75 $\mathrm{ml} / \mathrm{bottle}$ ) over a 48 to 72 -h period. The medium was concentrated 25 to 50 -fold $(3-5 \mathrm{ml})$ by ultrafiltration at $4^{\circ} \mathrm{C}$ (membrane series XM 100; Amicon Corp., Lexington, Mass.). The preparation contained $57 \% \beta$-hexosaminidase $A$ and $43 \% \beta$ hexosaminidase $\mathrm{B}$. This ratio was not appreciably changed if the enzyme secretions were collected over a short duration $(6 \mathrm{~h})$. It has been reported that fibroblast-derived $\beta$-hexosaminidase A and B do not differ in uptake properties (10).

Preparations containing "high-uptake" $\beta$-hexosaminidase were also obtained from roller bottle cultures. However, during collection, the serum-free medium contained $2 \mathrm{mM}$ mannose-6-phosphate and collection was for $24 \mathrm{~h}$. The medium was then concentrated as above and dialyzed overnight, first in $500 \mathrm{ml}$ saline and then $500 \mathrm{ml}$ serum-free medium to remove residual mannose-6-phosphate. Both enzyme preparations were stored at $-20^{\circ} \mathrm{C}$ until use.

$\beta$-Hexosaminidase assay. $\beta$-Hexosaminidase activity was assayed with the fluorogenic substrate 4-methylumbelliferyl$N$-acetyl-glucosaminide (Pierce Chemical Co., Rockford, Ill.). The assay system was as follows: $10 \mu \mathrm{l}$ of sample in $100 \mu \mathrm{l}$ of $5 \mathrm{mM}$ Huorogenic substrate in $0.1 \mathrm{M}$ citrate-phosphate buffer, $\mathrm{pH} 4.5$ (containing $0.05 \%$ bovine serum albumin and $0.01 \% \mathrm{NaN}_{3}$ ), was incubated for $30 \mathrm{~min}$ at $37^{\circ} \mathrm{C}$ in a water bath. The reaction was terminated by the addition of $3 \mathrm{ml}$ of $0.25 \mathrm{M}$ sodium carbonate-glycine buffer, $\mathrm{pH} 10$. Saturation kinetics are reached in this assay system, in contrast to a previously described procedure (11). One enzyme unit is the activity which liberates $1 \mathrm{nmol}$ of 4 -methylumbelliferone/h at $37^{\circ} \mathrm{C}$. Enzyme activity is expressed as microunits per cell $\left(10^{-6} \mathrm{U} /\right.$ cell $)$.

Mannose-6-phosphate inhibition of pinocytosis. To assess whether mannose-6-phosphate effectively inhibited pinocytosis of $\beta$-hexosaminidase, confluent monolayers of Sandhoff fibroblasts ( $\cong 10^{6}$ cells/monolayer) were preincubated for $24 \mathrm{~h}$ with and without $2 \mathrm{mM}$ mannose-6-phosphate (Sigma Chemical Co., St. Louis, Mo.) after which time either the normal fibroblast-excreted high- or low-uptake enzyme preparation was diluted up to five-fold in albumin-containing serum-free medium and added to the cultures for an additional $4 \mathrm{~h}$, and uptake was measured. Another set of cultures was incubated for $9 \mathrm{~d}$ in $2.5 \mathrm{ml}$ serum-free medium with or without $2 \mathrm{mM}$ D-mannose-6-phosphate. The culture fluids were replaced daily with or without addition of the inhibitor. Fibroblastexcreted $\beta$-hexosaminidase $(1,500 \mathrm{U} /$ flask $)$ was added to one set of cultures on day 1 and to another set on day 8 . Monolayers were harvested, extracted, and assayed $24 \mathrm{~h}$ after enzyme application. Endogenous residual activity of control Sandhoff fibroblasts was measured and subtracted from uptake values.

To determine the amount of $\beta$-hexosaminidase excreted by fibroblasts and taken back into cells through adsorptive pinocytosis, normal fibroblast cultures were maintained for
$9 \mathrm{~d}$ in $2.5 \mathrm{ml}$ of albumin-containing serum-free medium with or without $2 \mathrm{mM}$ mannose-6-phosphate. The media were harvested, and cultures reincubated daily in serum-free medium with or without fresh mannose-6-phosphate. The culture fluids were assayed daily for $\beta$-hexosaminidase activity to determine the extent to which the enzyme accumulated in the medium. Daily assays were performed to minimize possible enzyme inactivation in the medium. A second set of normal fibroblast cultures was similarly incubated with 10 $\mathrm{mM}$ mannose-6-phosphate to determine whether a higher dose of mannose-6-phosphate in the cultures would result in a greater accumulation of enzyme in the culture fluid. A concentration of $10 \mathrm{mM}$ was chosen because it was the highest concentration of the inhibitor that could be used without apparent toxic effects on the fibroblasts.

I-cell fibroblast cultures were also maintained in serumfree medium with or without $2 \mathrm{mM}$ mannose-6-phosphate as a control to determine whether mannose-6-phosphate had any effect on $\beta$-hexosaminidase secretion from fibroblasts.

As a control for the effect of $2 \mathrm{mM}$ mannose-6-phosphate on the stability or catalytic activity of $\beta$-hexosaminidase excreted from normal fibroblasts, duplicates of three different concentrations of $\beta$-hexosaminidase ranging from 360 to 1,440 $\mathrm{U} / \mathrm{ml}$ were incubated with $2 \mathrm{mM}$ mannose-6-phosphate (final concentration) at $37^{\circ} \mathrm{C}$ for $24 \mathrm{~h}$. No stabilizing or inactivating effect on enzyme activity was observed.

Half-life determination of $\beta$-hexosaminidase. The halflife of $\beta$-hexosaminidase was estimated by measuring the decay of internalized exogenous enzyme in Sandhoff fibroblast cultures over a period of several days. Excreted $\beta$ hexosaminidase was collected from roller bottle cultures of normal fibroblasts in the absence of mannose-6-phosphate. The medium was concentrated, centrifuged at $12,000 \mathrm{~g}$ for $10 \mathrm{~min}$, then filtered twice through Millex filter units $(0.22 \mu \mathrm{m}$; Millipore Corp., Bedford, Mass.) to ensure sterility. Monolayers were incubated with $800 \mathrm{U} / \mathrm{ml}$ of the preparation for $24 \mathrm{~h}$, after which time all flasks were washed free of excess enzyme with Hanks' balanced salt solution. Duplicate flasks were then harvested at this point and daily for up to $7 \mathrm{~d}$. Cells were extracted and assayed for $\beta$-hexosaminidase activity.

$K_{\text {uptake }}$ constant determination for $\beta$-hexosaminidase. Duplicate flasks of Sandhoff fibroblasts were incubated with increasing doses of either low- or high-uptake preparations of $\beta$-hexosaminidase derived from concentrated normal fibroblast culture fluid. The enzyme dosages ranged from 130 to $1,488 \mathrm{U} / \mathrm{ml}$. After $4 \mathrm{~h}$ incubation with enzyme preparations, cell monolayers were washed with Hanks' balanced salt solution, harvested, and extracted. The number of microunits of $\beta$-hexosaminidase taken up per cell was determined and corrected for endogenous activity. Standard double reciprocal plots of cellular activity vs. dose were constructed, and the apparent $K_{\text {uptake }}$ values were calculated from a linear regression line. The molar concentration of $\beta$-hexosaminidase was calculated from the specific activity of the purified enzyme (12) with the appropriate correction for the nonsaturation assay system used by these authors.

\section{RESULTS}

Our operational definition of low- and high-uptake forms of $\beta$-hexosaminidase in normal fibroblast culture fluid stems from the observation that in one case (lowuptake), $\beta$-hexosaminidase remains in the culture fluid (Fig. 1) and is taken up by Sandhoff fibroblasts with low efficiency (Table I), whereas in the other case (high-uptake) it requires competitive inhibition of up- 


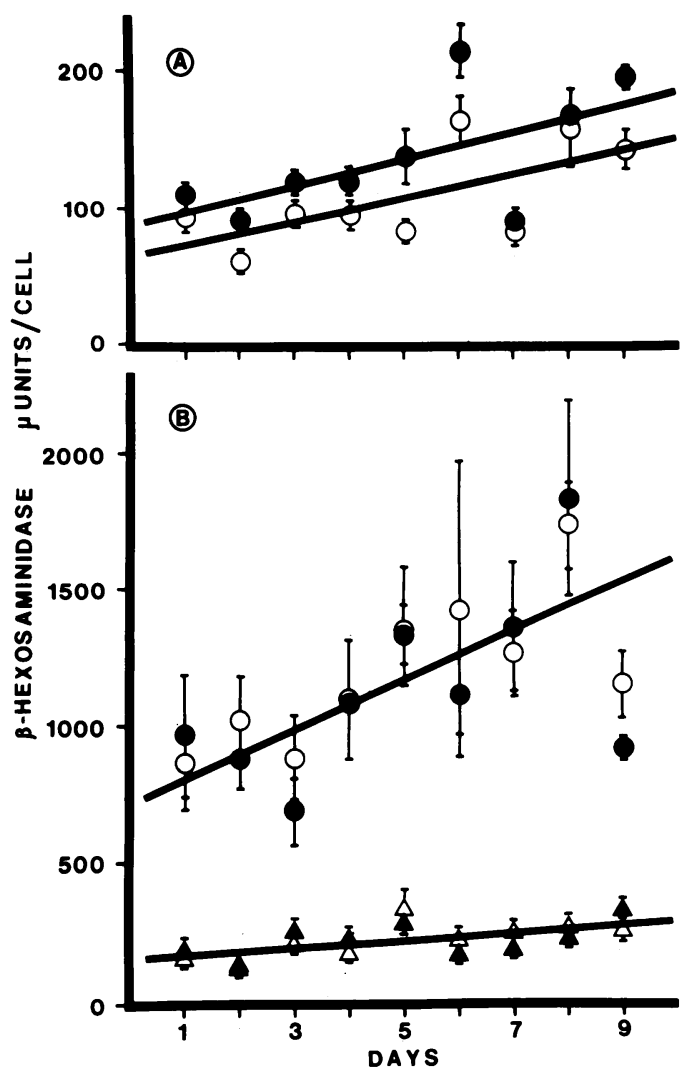

FigUre 1 Effect of D-mannose-6-phosphate on daily $\beta$-hexosaminidase activity in the culture medium (A) and in the cell extracts (B) of normal fibroblasts $(O, 0)$ and I-cell disease fibroblasts $(\Delta, \boldsymbol{\Delta}) . \bigcirc, \Delta$ : control cultures; $\boldsymbol{O}, \boldsymbol{\Delta}$ : cultures with $2 \mathrm{mM}$ D-mannose-6-phosphate. (A) Mean $\pm \mathrm{SE}$ of duplicate assays on 2-10 flasks. (B) Mean $\pm \mathrm{SE}$ of duplicate assays on two to seven flasks (normal fibroblasts); mean \pm mean deviations of duplicate assays on two flasks (I-cell fibroblasts).

take by $2 \mathrm{mM}$ mannose-6-phosphate to remain in the culture fluid (Fig. 1), and it is taken up more efficiently by Sandhoff fibroblasts (Table I).
Pinocytosis of both low- and high-uptake exogenous $\beta$-hexosaminidase by Sandhoff fibroblasts was inhibited $>96 \%$ by $2 \mathrm{mM}$ mannose-6-phosphate when the enzyme was added after $24 \mathrm{~h}$ preincubation of the monolayers with $2 \mathrm{mM}$ mannose-6-phosphate (Table I). After $8 \mathrm{~d}$ in serum-free medium, Sandhoff fibroblasts retained both their ability to pinocytose exogenous $\beta$-hexosaminidase and to be $>95 \%$ inhibited from internalizing enzyme in the presence of $2 \mathrm{mM}$ mannose-6phosphate. No toxic effects of prolonged exposure to $2 \mathrm{mM}$ mannose-6-phosphate were observed.

There was no statistically significant difference (paired $t$ test) in the intracellular activity of $\beta$-hexosaminidase between mannose-6-phosphate-treated and untreated normal fibroblast cultures (Fig. 1B). A gradual, slight increase in the overall enzyme activity in both cultures was observed (Fig. 1B). Hence both sets of data were pooled, and a linear regression line was calculated so that an estimate of the mean $\beta$-hexosaminidase activity could be made for any given day. There was also no statistical difference in the intracellular $\beta$-hexosaminidase concentration between treated and untreated I-cell fibroblast cultures (Fig. 1B).

There was a statistically significant difference, however $(P<0.01$ when all determinations were pooled), in the daily noncumulative excretion of $\beta$-hexosaminidase between mannose-6-phosphate-treated and untreated normal cultures. The daily excretion also increased with time. Therefore, to express the amount of excreted enzyme at any given time in terms of total intracellular and extracellular enzyme, regression lines were separately calculated from the daily excretion data (Fig. 1A).

Normal fibroblast cultures incubated for up to $9 \mathrm{~d}$ in serum-free medium with and without $2 \mathrm{mM}$ mannose-6-phosphate excreted $111 \pm 6(\mathrm{SE})$ to $196 \pm 7$, and $96 \pm 13$ to $144 \pm 13 \mu$ U/cell per day, respectively, so that by $9 \mathrm{~d}$ the mannose-6-phosphate-treated cultures built up significantly more enzyme in the medium than the

TABLE I

Inhibition of $\beta$-Hexosaminidase Uptake by D-Mannose-6-Phosphate*

\begin{tabular}{|c|c|c|c|c|}
\hline \multirow[b]{2}{*}{ Compound added } & \multicolumn{2}{|c|}{$\beta$-Hexosaminidase added $t$} & \multicolumn{2}{|c|}{ Cptakes } \\
\hline & Low-uptake & High-uptake & Low & $\mathrm{High}$ \\
\hline \multirow{3}{*}{$\begin{array}{l}\text { None } \\
\text { Man-6-PO }(2 \mathrm{mM})\end{array}$} & \multicolumn{2}{|c|}{$U / m l$} & \multicolumn{2}{|c|}{$\mu U / c e l l / 4 h$} \\
\hline & 810 & $1,293,1,348$ & $3.9 \pm 1.37^{\|}(100)$ & $52.7 \pm 5.46^{\top}(100)$ \\
\hline & 810 & $1,290,1,435$ & $0^{\Perp}(0)$ & $2.15 \pm 0.95^{\circ}(4)$ \\
\hline \multicolumn{5}{|c|}{$\begin{array}{l}\text { Percent uptake is given in parentheses. } \\
\text { * Pinocytosis of } \beta \text {-hexosaminidase was measured by using Sandhoff disease fib } \\
\text { described in Methods. } \\
+ \text { Prepared from normal skin fibroblast culture medium as described in Methods. } \\
\$ \text { Corrected for endogenous activity. } \\
\text { "Mean } \pm \mathrm{SE} \text { of triplicate flasks. } \\
\text { Mean } \pm \mathrm{SE} \text { of duplicate flasks. }\end{array}$} \\
\hline
\end{tabular}




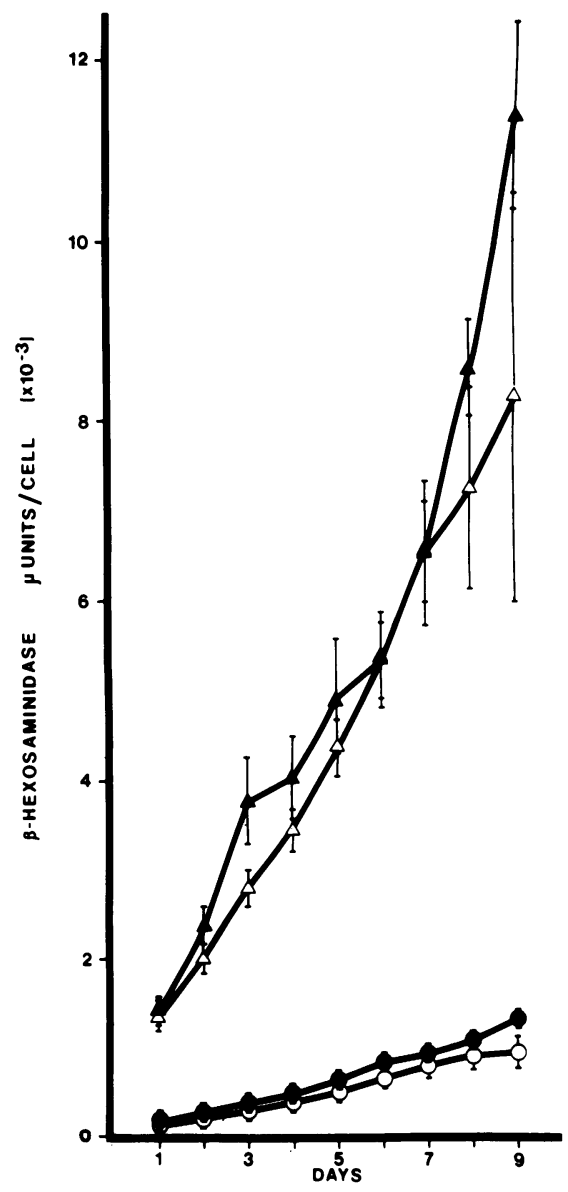

FIGURE 2 Effect of D-mannose-6-phosphate on cumulative $\beta$-hexosaminidase activity in culture medium of normal fibroblasts $(O, \boldsymbol{O})$ and I-cell fibroblasts $(\Delta, \boldsymbol{\Delta}) . \bigcirc, \triangle$ : control cultures; $\boldsymbol{O}, \boldsymbol{\Delta}$ : with $2 \mathrm{mM}$ D-mannose-6-phosphate. Mean $\pm \mathrm{SE}$ of duplicate assay on samples from 2-17 flasks.

untreated cultures $(P<0.01)($ Fig. 2$)$. Similar results were obtained in normal cultures incubated with 10 mM mannose-6-phosphate.

Because excreted I-cell disease enzyme is not usually pinocytosed $(2,9)$, an increase in extracellular enzyme in mannose-6-phosphate-treated I-cell disease cultures would indicate enhanced excretion. I-cell fibroblast cultures excreted 1,019 $\mu \mathrm{U} /$ cell per day when incubated with $2 \mathrm{mM}$ mannose-6-phosphate and 908 $\mu \mathrm{U} /$ cell per day without $2 \mathrm{mM}$ mannose-6-phosphate; the difference between treated and untreated cells was not statistically significant $(P>0.05)$ (Fig. 2$)$. The increase of $\beta$-hexosaminidase accumulation in mannose6-phosphate-treated normal cultures, therefore, was the result of impaired uptake alone.

A half-life of $2.6 \mathrm{~d}$ for $\beta$-hexosaminidase in fibroblasts was determined from an exponential decay curve calculated from the percent enzyme remaining inside Sandhoff cells on successive days after the initial 24 -h uptake period (Fig. 3). It should be emphasized that endogenous $\beta$-hexosaminidase activity in control Sandhoff cells was taken into account daily because this activity tends to increase with time in "step-down" conditions when the cells are in serum-free medium (13).

An apparent $K_{\text {uptake }}$ of $0.476 \mu \mathrm{M}$ was estimated for low-uptake $\beta$-hexosaminidase, whereas the highuptake enzyme had an apparent $K_{\text {uptake }}$ of $3.3 .4 \mathrm{nM}$ when the data were analyzed in terms of enzyme kinetics (Fig. 4). From our inhibition of reuptake experiments (Fig. 1), however, only $20 \%$ of the highuptake preparation is in fact internalized by normal fibroblasts in the absence of mannose-6-phosphate (Fig. 1). Therefore, this fraction represents the actual high-uptake component of the preparation. Considering that both high- and low-uptake forms are endocytosed through the same mannose-6-phosphate-inhibitable system (Table I), and that there is at least one order of magnitude difference in the apparent $K_{\text {uptake }}$ values (Fig. 4), then the apparent $K_{\text {uptake }}$ of the mixture is mainly attributable to the high-uptake enzyme fraction ( $20 \%$ of total). If the $K_{\text {uptake }}$ is calculated on the

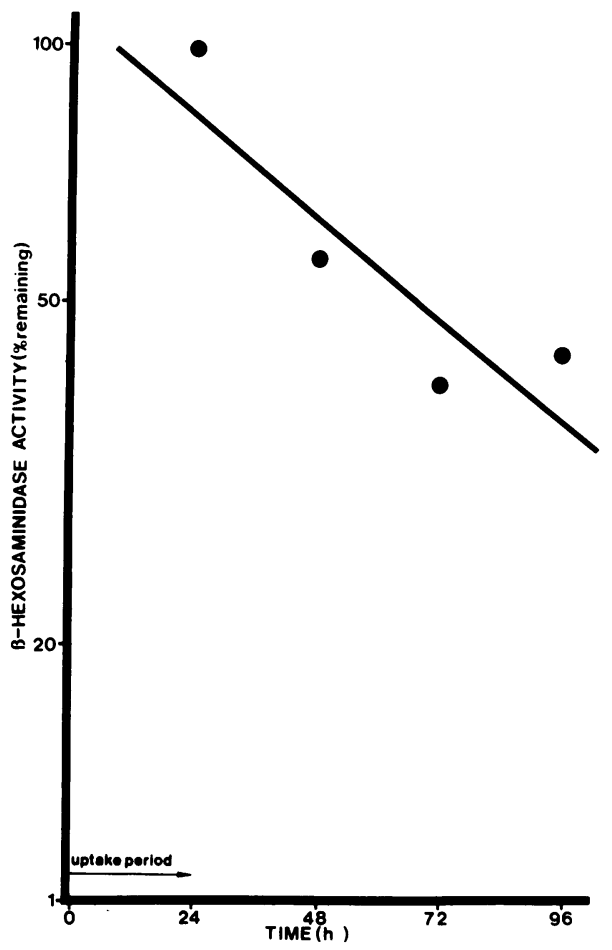

FIGURE 3 Decay of $\beta$-hexosaminidase internalized by Sandhoff disease fibroblasts after a 24 -h uptake period. In four separate experiments, the residual activity in the cells, corrected for endogenous activity, was expressed as a percentage of the activity at the end of the uptake period. An exponential equation was calculated $\left(y=83.78 e^{-(0.011 x)} ; r^{2}=0.74\right)$ which gave the best fit to the means of the normalized values. The resulting half-life was $61 \mathrm{~h}$. 


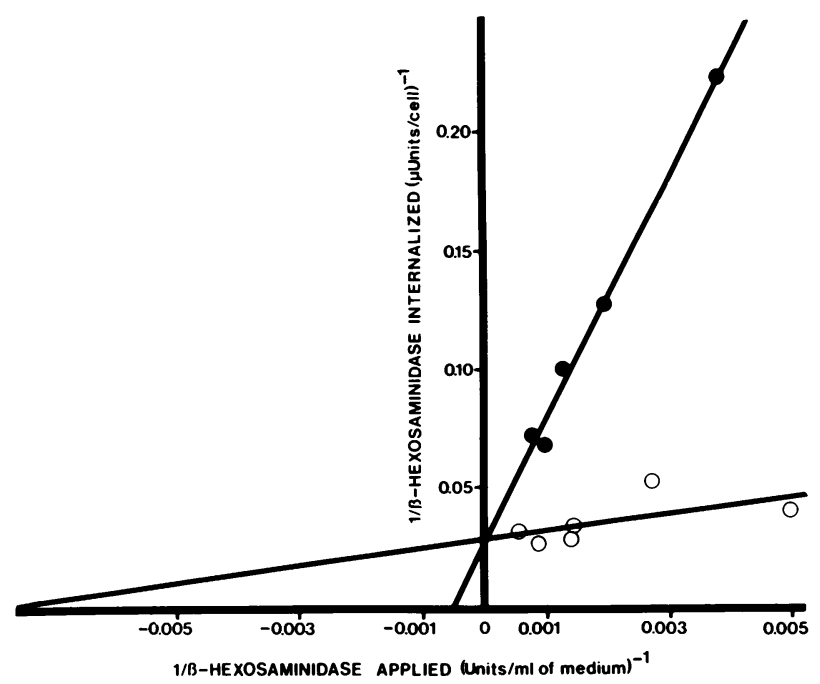

Figure 4 Endocytosis by Sandhoff disease fibroblasts of $\beta$ hexosaminidase from low-uptake $(\bigcirc)$ and high-uptake $(O)$ culture fluid preparations. The concentration of enzyme applied varied between 130 and $1,500 \mathrm{U} / \mathrm{ml}$. The apparent $K_{\text {uptake }}$ was obtained by fitting a regression line to the experimental data by the least squares method.

basis of $\cong 20 \%$ of the applied dose, a value of $K \cong 6.7$ $\mathrm{nM}$ is obtained; this value is of the same order of magnitude as those obtained for purified high-uptake $\alpha$ L-iduronidase and $\beta$-glucuronidase $(5,14)$.

\section{DISCUSSION}

The data obtained with the inhibition of exogenous enzyme uptake by Sandhoff fibroblasts (Table I) indicate that constant exposure of the normal cultures to $2 \mathrm{mM}$ mannose-6-phosphate renewed daily can effectively inhibit the uptake of endogenous excreted enzyme. The dosage of $\beta$-hexosaminidase used in the uptake inhibition experiments with Sandhoff fibroblasts (Table I) was chosen to exceed the amount of enzyme usually accumulated daily in I-cell fibroblast cultures $(\cong 400-600 \mathrm{U} / \mathrm{ml})$. If I-cell disease results from an impaired uptake of hydrolases normally excreted (2), then the activity that accumulates in I-cell medium in $24 \mathrm{~h}$ should represent the amount theoretically excreted by, and taken back into, normal fibroblasts in $24 \mathrm{~h}$. Hence the concentration of mannose6-phosphate that inhibits the uptake at two to five times higher concentrations of exogenous enzyme by Sandhoff fibroblasts in $24 \mathrm{~h}$ should even more effectively inhibit the reuptake of enzyme theoretically excreted by normal fibroblasts in $24 \mathrm{~h}$.

The effectiveness of $2 \mathrm{mM}$ mannose-6-phosphate inhibition is validated by the following considerations. Adsorptive endocytosis can be considered analogous to an enzymatic reaction, and can be analyzed in terms of classic enzyme kinetics $(5,15,16)$. If we assume that the inhibition constant, $K_{\mathrm{i}}$, of mannose-6-phosphate for $\beta$-hexosaminidase uptake is of the same order of magnitude as that found for $\beta$-glucuronidase and $\alpha$ L-iduronidase uptake, i.e., $30-50 \mu \mathrm{M}(5,14)$, it can be calculated (15) that endocytosis of $\beta$-hexosaminidase of the low-uptake form $\left(K_{\text {uptake }} 0.48 \mu \mathrm{M}\right)$ should be inhibited $>99 \%$ at the concentrations used (Table I). Analogously, endocytosis of the high-uptake enzyme ( $K_{\text {uptake }} 6.7 \mathrm{nM}$ ), which constitutes only $20 \%$ of total in the high-uptake preparation, should be inhibited $>95 \%$. These predicted figures correspond closely with those obtained experimentally (Table I). Thus, $2 \mathrm{mM}$ mannose-6-phosphate can effectively inhibit reuptake of high- and low-uptake enzyme forms at the enzyme concentrations predicted by the Hickman and Neufeld hypothesis (2).

If all the newly synthesized enzyme in cultured fibroblasts must be excreted and taken back into the cells to be packaged in lysosomes, then by $2.6 \mathrm{~d}$, which is the half-life of $\beta$-hexosaminidase internalized by Sandhoff fibroblasts in serum-free medium, the normal fibroblasts should excrete and pinocytose one-half of the total intracellular and excreted $\beta$-hexosaminidase. From our data, if the enzyme excreted daily and not taken back because of the inhibition by mannose-6phosphate is expressed as a percentage of the total daily intracellular and excreted enzyme, by $2.6 \mathrm{~d}$ only $6 \%$ of this total activity has accumulated in the medium (Fig. 1). Therefore, our data indicate that the mannose-6-phosphate-inhibitable excretion and reuptake route can only account for $\cong 12 \%$ of the total $\beta$-hexosaminidase in cultured fibroblasts.

An independent confirmation of our results can be found in recent experiments by Halley et al. (17), who studied the exchange of $\beta$-hexosaminidase through the medium in co-cultivation experiments with Sandhoff disease and normal fibroblasts. From their data, it can be calculated that only about $14 \%$ of total $\beta$-hexosaminidase engages in the excretion-reuptake route.

Although apparently involving a small fraction of total enzyme, the excretion-reuptake route may still have a physiological role in cell metabolism. For instance, it has been shown that significant correction of glycosaminoglycan catabolism takes place in mucopolysaccharidosis II-cultured fibroblasts after uptake of only $2-5 \%$ of normal cellular concentrations of $\alpha$ acetylglucosaminidase (18). Not all lysosomal enzymes are necessarily involved in excretion and reuptake by neighboring fibroblasts, however, as intercellular exchange of $\alpha$-glucosidase and $\beta$-galactosidase was not observed $(17,19)$.

If the defect in I-cell disease were an impairment of reuptake because of an altered recognition marker (2), then preventing the reuptake of $\beta$-hexosaminidase excreted by normal fibroblasts should result in an enzyme concentration in the medium approaching that found 
in I-cell fibroblast medium. As shown in Fig. 2, even after $9 \mathrm{~d}$ incubation, the cumulative differential excretion due to mannose-6-phosphate inhibition of reuptake does not approach the levels in I-cell cultures. In fact, the mannose-6-phosphate-treated normal cultures have accumulated in their medium only $5 \%$ of the enzyme accumulated in the I-cell fibroblast cultures in the same period (Fig. 2). It could be argued that mannose-6-phosphate inhibits excretion of $\beta$ hexosaminidase by normal cells. However, as shown by the treatment of I-cell fibroblast cultures with mannose-6-phosphate (Fig. 2), excretion is not affected.

The intracellular activity of mannose-6-phosphatetreated normal fibroblasts did not decrease over a 9-d period. In fact, the activity increased in both the treated and untreated cells despite a daily loss to the medium of 11.5 and $9 \%$, respectively, of the mean intracellular activity. A stepdown effect (13) presumably masked the small loss of intracellular enzyme in normal fibroblast cultures. At any rate, by simply inhibiting the reuptake of a small fraction of excreted enzyme, it is not possible to produce a phenocopy of I-cell disease.

If the only abnormality in I-cell disease were impaired uptake due to an altered recognition marker, then the enzyme found in the I-cell culture medium should represent only that $12 \%$ of the newly synthesized enzyme which in normal cells is engaged in the excretion-reuptake route. I-cell fibroblasts excrete $\cong 1,000 \mu \mathrm{U} /$ cell per day (Fig. 2), whereas their intracellular concentration is relatively constant (Fig. 1B). Therefore at least $1,000 \mu \mathrm{U} /$ cell are synthesized daily, and of these about 880 should not engage in the excretion-reuptake route and should be retained inside the cells. However, the observed intracellular activity $(100-300 \mu \mathrm{U} /$ cell) is only $11-34 \%$ of the expected activity. Therefore, it appears that I-cell fibroblasts constantly lose the newly synthesized enzyme to the medium through an abnormal excretion process.

From our data we conclude that an excretionreuptake route of lysosomal enzyme processing through a phosphomannose recognition mechanism in normal fibroblasts only accounts for $12 \%$ of the total enzyme, and the extracellular buildup of $\beta$-hexosaminidase and probably other lysosomal enzymes in I-cell disease is not a result of an inability to recapture excreted enzyme through a mechanism inhibitable by $2 \mathrm{mM}$ mannose-6-phosphate. Our observations are limited to a mannose-6-phosphate-specific uptake, but most evidence so far points to this as the major route of receptor-mediated uptake of human fibroblast-excreted enzymes by human fibroblasts $(4,5,7)$.

Sly and Stahl (20) have postulated that very high affinity forms of lysosomal enzymes exist which appear at the cell surface, are not released into the culture fluid, and are rapidly reinternalized for final proces- sing. Although these forms could not explain the crosscorrection observed in fibroblast cultures without cellular contact (17), an alternative cell surface-mediated pathway for lysosomal enzyme processing could still exist (21).

Our experiments have demonstrated the existence of high- and low-uptake forms of $\beta$-hexosaminidase derived from normal fibroblast excretions. We cannot exclude the possibility that the low-uptake form consists of a small amount of high-uptake enzyme in combination with a "no-uptake" form. High- and low-uptake forms of human $\alpha$ - $N$-acetylglucosaminidase (6), $\alpha$ mannosidase A (6), $\alpha$-L-iduronidase (5), and $\beta$-glucuronidase (22) have been reported by others. We cannot exclude the existence of a $\beta$-hexosaminidase form with greater affinity for the uptake mechanism than that of the high-uptake form we observed. Inasmuch as cultures exposed to $10 \mathrm{mM}$ mannose-6-phosphate did not accumulate significantly more enzyme in the medium than those with $2 \mathrm{mM}$ mannose-6-phosphate, it can be reasoned kinetically (15) that a very high affinity form should have a $K_{\text {uptake }}$ lower than $\cong 1 \mathrm{nM}$.

We have proposed that the abnormal extracellular concentration of lysosomal enzymes in I-cell disease fibroblast cultures results from preferential exocytosis (8), associated with abnormal glycosylation of enzymes (9). The data presented here, considering the limitations of the in vitro system with individual cell lines, support our hypothesis because it appears that impairment of reuptake cannot account for the observed intraand extracellular enzyme levels in I-cell fibroblast cultures.

\section{ACKNOWLEDGMENTS}

We thank Miss Valerie Amigone for her excellent technical assistance.

This work was supported by National Science Foundation grant PCM 77-05733, National Institutes of Health grant 1-RO113677, Health, Education, and Welfare Maternal and Child Health Service (project 417), and Biomedical Research Support grant RR-05493 from the Division of Research Resources, National Institutes of Health.

\section{REFERENCES}

1. Wiesmann, U. N., J. Lightbody, and N. N. Herschkowitz. 1971. Multiple lysosomal enzyme deficiency due to enzyme leakage? N. Engl. J. Med. 284: 109-110.

2. Hickman, S., and E. F. Neufeld. 1972. A hypothesis for I-cell disease: defective hydrolases that do not enter lysosomes. Biochem. Biophys. Res. Commun. 49: 992999.

3. Hickman, S., L. J. Shapiro, and E. F. Neufeld. 1974. A recognition marker required for uptake of a lysosomal enzyme by cultured fibroblasts. Biochem. Biophys. Res. Commun. 57: 55-61.

4. Kaplan, A., D. Fischer, D. Achord, and W. Sly. 1977. Phosphohexosyl recognition is a general characteristic of pinocytosis of lysosomal glycosidases by human fibroblasts. J. Clin. Invest. 60: 1088-1093. 
5. Sando, G., and E. F. Neufeld. 1977. Recognition and receptor-mediated uptake of a lysosomal enzyme, $\alpha$ L-iduronidase, by cultured human fibroblasts. Cell. 12: $619-627$.

6. Ullrich, K., G. Mersmann, E. Weber, and K. von Figura. 1978. Evidence for lysosomal enzyme recognition by human fibroblasts via a phosphorylated carbohydrate moiety. Biochem. J. 170: 643-650.

7. Kaplan, A., D. Fischer, and W. S. Sly. 1978. Correlation of structural features of phosphomannans with their ability to inhibit pinocytosis of human $\beta$-glucuronidase by human fibroblasts. J. Biol. Chem. 253: 647-650.

8. Vladutiu, G. D., and M. C. Rattazzi. 1975. Abnormal lysosomal hydrolases excreted by cultured fibroblasts in I-cell disease (mucolipidosis II). Biochem. Biophys. Res. Commun. 67: 956-964.

9. Vladutiu, G. D., and M. C. Rattazzi. 1978. I-cell disease: desialylation of $\beta$-hexosaminidase and its effect on uptake by fibroblasts. Biochim. Biophys. Acta. 539: 31-36.

10. Cantz, M., and H. Kresse. 1974. Sandhoff disease: defective glycosaminoglycan catabolism in cultured fibroblasts and its correction by $\beta-N$-acetylhexosaminidase. Eur. J. Biochem. 47: 581-590.

11. Vladutiu, G. D., P. J. Carmody, and M. C. Rattazzi. 1975. Immunoaffinity chromatography of human $\beta$-hexosaminidase A. Prep. Biochem. 5: 147-159.

12. Geiger, B., and R. Arnon. 1976. Chemical characterization and subunit structure of human $N$-acetylhexosaminidase A and B. Biochemistry. 15: 3484-3493.

13. Kaplan, J. 1978. Modulation of lysosomal enzyme levels in cultured cells. Arch. Biochem. Biophys. 187: 376-386.

14. Kaplan, A., D. T. Achord, and W. S. Sly. 1977. Phosphohexosyl components of a lysosomal enzyme are recog- nized by pinocytosis receptors on human fibroblasts. Proc. Natl. Acad. Sci. U. S. A. 74: 2026-2030.

15. Dixon, M., and E. C. Webb. 1964. Enzymes. Longman, Group Ltd. London. 318-322.

16. Normann, S. J. 1974. Kinetics of phagocytosis. II. Analysis of in vivo clearance with demonstration of competitive inhibition between similar and dissimilar foreign particles. Lab. Invest. 31: 161-169.

17. Halley, D. J. J., H. A. de Wit-Verbeek, A. J. J. Reuser, and H. Galjaard. 1978. The distribution of hydrolytic enzyme activities in human fibroblast cultures and their intercellular transfer. Biochem. Biophys. Res. Commun. 82: $1176-1182$.

18. O'Brien, J. S., A. L. Miller, A. W. Loverde, and M. L. Veath. 1973. Sanfilippo disease type B: enzyme replacement and metabolic correction in cultured fibroblasts. Science (Wash. D. C.). 181: 753-755.

19. Reuser, A., D. Halley, E. deWit et al. 1976. Intercellular exchange of lysosomal enzymes: enzyme assays in single human fibroblasts after co-cultivation. Biochem. Biophys. Res. Commun. 69: 311-318.

20. Sly, W. S., and P. Stahl. 1978. Receptor-mediated uptake of lysosomal enzymes. In Transport of Macromolecules in Cellular Systems. S. Silverstein, editor. Dahlem Konferenzen, W. Berlin. 1-15.

21. Lloyd, J. B. 1977. Cellular transport of lysosomal enzymes. An alternative hypothesis. Biochem. J. 164: 281282.

22. Glaser, J. H., K. J. Roozen, F. E. Brot, and W. S. Sly. 1975. Multiple isoelectric and recognition forms of human $\beta$-glucuronidase activity. Arch. Biochem. Biophys. 166: 536-542. 